\title{
Emerging treatment options for early mycosis fungoides
}

\section{Montserrat Fernandez- Guarino \\ Department of Dermatology, Hospital Central de la Cruz Roja, Madrid, Spain}

Correspondence: Montserrat Fernandez-Guarino Hospital Central de la Cruz Roja, Avenida de Reina Victoria numero 24, Madrid 28003, Spain

Tel +34914538300

Fax +34 9I 5346066

Email montsefdez@msn.com
This article was published in the following Dove Press journal:

Clinical, Cosmetic and Investigational Dermatology

16 February 2013

Number of times this article has been viewed

\begin{abstract}
Mycosis fungoides is a candidate for skin-directed therapies in its initial stages. In recent years, therapeutic options outside of the normal treatment recommendations such as topical imiquimod, topical tazarotene, topical methotrexate, excimer light sources, and photodynamic therapy have been published with variable results. These alternatives have been useful in cases of localized mycosis fungoides that do not respond to routine treatments; nevertheless, more studies on these methods are still needed. This article summarizes the literature and data that are known so far about these treatments.
\end{abstract}

Keywords: mycosis fungoides, topical treatments, excimer light, photodynamic therapy

\section{Introduction}

Mycosis fungoides (MF) is the most common primary cutaneous lymphoma. It is calculated that it represents approximately $50 \%$ of primary cutaneous lymphomas, with an incidence estimated at 0.36 cases for every 100,000 individuals/year. ${ }^{1} \mathrm{MF}$ is a low-grade cutaneous lymphoma caused by CD4+ T-lymphocytes that are atypical and with a cerebriform nucleus that infiltrates the skin characteristically with epidermotropism. ${ }^{2} \mathrm{MF}$ is classically divided according to its clinical presentation in patches, plaques, or tumors, although there is a wide variety of presentations. All of these were included in the World Health Organization-European Organization for Research and Treatment of Cancer (EORTC) classification as "MF and its varieties and subtypes." Later, a new revision of the staging and classification was proposed by the International Society for Cutaneous Lymphomas (ISCL)-EORTC in $2007 .^{3}$

The etiopathogenesis of MF is not clear and it still has not been confirmed whether the T-lymphocytes that make up the infiltrate that is characteristic of this dermatosis are reactive to autoantigens and whether their proliferation produces a lymphoma or if it is a de novo neoplastic proliferation. ${ }^{4}$ The accumulation of lymphocytes in the skin appears to be due to a failure in apoptosis rather than an increase in proliferation. ${ }^{5}$

The prognosis and survival depends on the stage at diagnosis. Table 1 summarizes the staging of MF proposed by the ISCL-EORTC in $2007,{ }^{3}$ which was recently used in 2011 for defining the clinical end points and response criteria. ${ }^{6}$ Stages IA, IB, and IIA are classified as "early-stage MF." These stages include involvement of the skin in the form of patches, papules, or plaques (T1-T2) without tumors or erythroderma, clinical lymph node involvement (nodes larger than $1.5 \mathrm{~cm}$ ), confirmed or not 
Table I Modified International Society for Cutaneous Lymphomas/ European Organization for Research and Treatment of Cancer revisions to the tumor-node-metastasis-blood classification of mycosis fungoides/Sezary syndrome

\begin{tabular}{|c|c|}
\hline TNMB & Description \\
\hline \multicolumn{2}{|l|}{ Skin } \\
\hline TI & $\begin{array}{l}\text { Limited patches, papules, and/or plaques covering }<10 \% \\
\text { of the skin surface }\end{array}$ \\
\hline $\mathrm{T} 2$ & Patches, papules, or plaques covering $\geq 10 \%$ of the skin surface \\
\hline T3 & One or more tumors ( $\geq 1 \mathrm{~cm}$ diameter) \\
\hline $\mathrm{T} 4$ & Confluence of erythema covering $\geq 80 \%$ body surface area \\
\hline \multicolumn{2}{|l|}{ Node } \\
\hline No & No clinically abnormal lymph nodes \\
\hline \multirow[t]{2}{*}{$\mathrm{NI}$} & Clinically abnormal lymph nodes; histopathology \\
\hline & Dutch grade I or NCI LNO-LN2 \\
\hline \multirow[t]{2}{*}{ N2 } & Clinically abnormal lymph nodes; histopathology \\
\hline & Dutch grade 2 or $\mathrm{NCI}$ LN3 \\
\hline \multirow[t]{2}{*}{ N3 } & Clinically abnormal lymph nodes; histopathology \\
\hline & Dutch grade 3 or NCI LN4 \\
\hline \multirow[t]{2}{*}{ NX } & Clinically abnormal lymph nodes without histologic confirmation \\
\hline & or inability to fully characterize the histologic subcategories \\
\hline \multicolumn{2}{|r|}{ 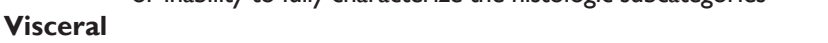 } \\
\hline Mo & No visceral organ involvement \\
\hline MI & $\begin{array}{l}\text { Visceral involvement (must have pathology confirmation } \\
\text { and organ involved should be specified) }\end{array}$ \\
\hline \multicolumn{2}{|r|}{ 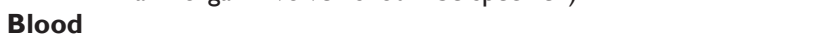 } \\
\hline BO & $\begin{array}{l}\text { Absence of significant blood involvement: }<5 \% \text { of peripheral } \\
\text { blood Sezary cells }\end{array}$ \\
\hline BI & Low blood tumor burden: $>5 \%$ of peripheral blood Sezary cells \\
\hline \multirow[t]{5}{*}{ B2 } & High blood tumor burden: $\geq 1000 / \mu \mathrm{L}$ Sezary cells \\
\hline & $\begin{array}{l}\text { with positive clone } \\
\text { One of the following can be substituted for Sezary cells: }\end{array}$ \\
\hline & - CD4/CD8 cells $\geq 10 \%$ \\
\hline & - CD4+/CD7- cells $\geq 40 \%$ \\
\hline & - CD4+/CD26- cells $\geq 30 \%$ \\
\hline Stage & TNMB \\
\hline IA & $\mathrm{TI}, \mathrm{N} 0, \mathrm{MO}, \mathrm{BO}-\mathrm{BI}$ \\
\hline IB & $\mathrm{T} 2, \mathrm{NO}, \mathrm{MO}, \mathrm{BO}-\mathrm{BI}$ \\
\hline IIA & TI-T2, NI-N2-NX, MO, BO-BI \\
\hline IIB & T3, NO-NI-N2-NX, MO, BO \\
\hline IIIA & T4, No-NI-N2-NX, M0, B0 \\
\hline IIIB & T4, No-NI-N2-NX, M0, BI \\
\hline IVAI & TI-T4, N0-NI-N2-NX, M0, B2 \\
\hline IVA2 & TI-T4, N3, M0, B0-B2 \\
\hline IVB & TI-T4, NI-N2-N3-NX, MI, B0-B2 \\
\hline
\end{tabular}

Notes: () 201I. American Society of Clinical Oncology. All rights reserved. Reproduced with permission from Olsen EA, Whittaker S, Kim YH, et al. Clinical end points and response criteria in mycosis fungoides and Sezary syndrome: a consensus statement of the International Society for Cutaneous Lymphomas, the United Stated Cutaneous Lymphoma Consortium, and the cutaneous lymphoma task force of the European Organisation for Research and Treatment of Cancer. J Clin Oncol. 20I I;29(18):2598-2607.6 Data obtained from Olsen E, Vonderheid E, Pimpinelli N, et al. Revisions to the staging and classification of mycosis fungoides and Sezary syndrome: a proposal of the International Society for Cutaneous Lymphomas (ISCL) and the cutaneous task force of the European Organization for Research and Treatment of Cancer (EORTC). Blood. 2007; I 10(6): 17|3-1722. ${ }^{3}$

Abbreviations: $\mathrm{NCl}$, National Cancer Institute; TNMB, tumor-node-metastasisblood.

by histology - and if confirmed does not surpass grade 2 of the Dutch histopathology scale (LN0-LN1), and absence of visceral metastases. The diagnosis of early-stage MF is sometimes difficult; Table 2 summarizes an algorithm of diagnosis of early-stage MF developed by the ISCL. ${ }^{8}$
This article reviews the emerging therapies at the onset of MF, but it is important to remember that these are currently therapeutic alternatives that still require more study and are not considered in treatment guidelines.

\section{General therapeutic approximation at early-stage MF}

Variability in the clinical presentation and progression of MF makes multiple therapeutic options available, although its management is complex and there are no simple treatment algorithms. Treatment recommendations on the treatment of MF and Sezary syndrome have been published and updated. These include the guidelines from the National Cancer Center Network (http://www.nccn.org) ${ }^{9}$ updated in 2012 and the 2008 recommendations of the European Society of Medical Oncology. ${ }^{10}$ In 2011, the ISCL-EORTC and the United States Cutaneous Lymphoma Consortium published the clinical end points and response criteria for the treatments used in MF., ${ }^{3,6}$ Other important authors, leading experts in cutaneous lymphomas, have recently reviewed the literature published in the treatment of cutaneous lymphomas, adding their own experience. ${ }^{11}$

It is important to note that there are very few clinical trials on MF as it is a very uncommon dermatosis. Therefore, the evidence upon which these guidelines and recommendations are based is limited. Conversely, in addition to the recommendations from treatment guidelines, there is a multitude of factors to take into account when planning treatment for a patient with MF - both availability and patient factors. Management of these patients is multidisciplinary, involving a hematologist and oncologist. This review will attempt to show the dermatological perspective.

In the management of early-stage MF, skin-directed therapies are suggested in two forms: "skin-limited therapies" for limited or localized disease and "skin-generalized therapies" for generalized skin involvement. ${ }^{9-11}$ These options are summarized in Table 3. It is important to note that the majority of patients present with early-stage MF and the initial treatment is skin-directed therapy. The aim of treatment in early-stage MF is to control skin lesions while minimizing morbidity and limiting toxicity, as the early application of therapy in early-stage MF does not impact on survival. ${ }^{11,12}$ Topical corticoids are the most common treatment for patients with limited patch disease. Potent corticoids are the most effective, with a $60 \%-65 \%$ complete response rate. ${ }^{13}$ Other choices for topical treatment are topical chemotherapy using metochlorethamine (nitrogen mustard) or carmustine. However, the use of these agents is often complicated by their availability (they require pharmacy 
Table 2 Algorithm of diagnosis of early-stage mycosis fungoides ${ }^{8}$

\begin{tabular}{|c|c|c|c|c|c|}
\hline & \multicolumn{3}{|l|}{ Criteria } & \multicolumn{2}{|l|}{ Scoring system } \\
\hline & Basic & Additional & Other & Two points & One point \\
\hline Clinical & $\begin{array}{l}\text { Persistent and/or } \\
\text { progressive patches/ } \\
\text { thin plaques }\end{array}$ & $\begin{array}{l}\text { Not in a sun-exposed location } \\
\text { Size/shape variation } \\
\text { Poikilodermia }\end{array}$ & & $\begin{array}{l}\text { Two points for basic } \\
\text { criteria and two } \\
\text { additional criteria }\end{array}$ & $\begin{array}{l}\text { One point for basic } \\
\text { criteria and one } \\
\text { additional criteria }\end{array}$ \\
\hline Histopathologic & $\begin{array}{l}\text { Superficial lymphoid } \\
\text { infiltrate }\end{array}$ & $\begin{array}{l}\text { Epidermotropism without } \\
\text { spongiosis } \\
\text { Lymphoid atypia }\end{array}$ & & $\begin{array}{l}\text { Two points for basic } \\
\text { criteria and two } \\
\text { additional criteria }\end{array}$ & $\begin{array}{l}\text { One point for basic } \\
\text { criteria and one } \\
\text { additional criteria }\end{array}$ \\
\hline Molecular biologic & & & $\begin{array}{l}\text { Clonal T-cell receptor } \\
\text { gene rearrangement }\end{array}$ & & $\begin{array}{l}\text { One point for } \\
\text { clonality }\end{array}$ \\
\hline Immunopathologic & & & $\begin{array}{l}<\mathrm{CD} 2+, \mathrm{CD} 3+\text {, and/or } \\
\text { CD5+ cells } \\
<10 \% \text { CD7 cells } \\
\text { Epidermal/dermal } \\
\text { discordance of CD2, CD3, } \\
\text { CD5, or CD7 (deficiency) }\end{array}$ & & $\begin{array}{l}\text { One point for one } \\
\text { or more criteria }\end{array}$ \\
\hline
\end{tabular}

preparation) and frequent secondary effects (irritation, drug hypersensitivity, cutaneous malignancy).${ }^{14}$ Topical bexarotene gel is another option for the topical treatment of plaques of MF; however, it has lower reponse rates and is an expensive treatment that is sometimes difficult to acquire. ${ }^{15}$ For widespread plaques, phototherapy with psoralen plus ultraviolet A (PUVA) or ultraviolet B (UVB) is recommended. Complete response rates to PUVA are aproximately $95 \%$ and $75 \%-83 \%$ to UVB. Remission with phototherapy is often pronlonged; however, remission is shorter with UVB, which is also less effective than PUVA in thick plaques. Phototherapy is generally well tolerated; however, nausea is sometimes an acute side effect from the oral psoralen and phototoxicity. ${ }^{16,17}$ An increased rate of skin malignancies including squamous cell carcinoma and melanoma have been described in PUVA as a long-term adverse effect. ${ }^{18,19}$ Radiotherapy is a highly effective therapy in MF and can be used for both early- and advanced-stage disease. ${ }^{14}$ Table 4 summarizes the efficacy of these skin-directed therapies and their advantages, disadvantages, and secondary effects. ${ }^{11,14-19}$

In addition to these treatments, there are other options of skin-limited treatments that have recently been developed and applied that will be explained throughout this review.

Table 3 Recommended skin therapies for early-stage mycosis fungoides 9

\begin{tabular}{ll}
\hline Localized involvement & Generalized involvement \\
\hline Topical corticosteroids & Topical corticosteroids \\
Topical chemotherapeutics & Topical chemotherapeutics \\
(nitrogen mustard, carmustine) & (nitrogen mustard, carmustine) \\
Local radiation therapy & Phototherapy: UVB, PUVA \\
Topical retinoids & Total skin electron beam \\
Phototherapy: UVB, PUVA & therapy \\
\hline
\end{tabular}

Abbreviations: PUVA, psoralen plus ultraviolet $A$; UVB, ultraviolet $B$.

\section{Photodynamic therapy (PDT)}

In 1994, Svanberg et al published good results in the treatment of an MF plaque with PDT. ${ }^{20}$ Since then, its use has increased in recent years, although there is still insufficient experience and clinical trials. PDT has been shown to be useful as a skinlimited treatment in localized forms of MF that do not respond to regular treatments (Table 3). The thickness of the lesion is important for applying this technique. Therefore, tumor forms or more infiltrated plaques are not candidates for PDT due to the limited penetration of light in the skin.

\section{Mechanism of action}

The mechanism by which PDT may act on plaques of MF has been described. In 1994, Boehncke et al demonstrated that PDT inhibits proliferation of lymphocytes in MF plaques in both in vitro and in vivo studies. ${ }^{21}$ In 1995, RittenhouseDiakun et al demonstrated that malignant lymphocytes from MF lesions express a higher amount of CD71 or transferrin receptor than normal lymphocytes and that this receptor gives them a greater capacity to absorb iron and accumulate higher levels of intracellular protoporphyrin IX, making them more sensitive to treatment with PDT. ${ }^{22}$ In 2000, Edstrom et al also demonstrated a reduction in CD71+ lymphocytes in the infiltrate of MF plaques after treatment with PDT due to a decrease in their proliferation. ${ }^{23}$ In 1998, Edstrom et al had demonstrated a reduction in typical CD4+/CD7- lymphocytes in MF plaques after treatment with PDT due to a decrease in their proliferation without demonstrating the existence of involved apoptotic mechanisms. ${ }^{24}$ All of these findings suggest that PDT has the capacity to selectively destroy malignant lymphocytes in MF lesions. 
Table 4 Summary of the efficacy, indications, advantages/disadvantages, and adverse effects of skin-directed therapies in plaques of mycosis fungoides

\begin{tabular}{|c|c|c|c|c|}
\hline Treatment & Complete response & Advantages & Disadvantages & Adverse effects \\
\hline Topical corticoids & $\begin{array}{l}60 \%-65 \% \text { in } \mathrm{Tl} \\
25 \% \text { in } \mathrm{T} 2\end{array}$ & $\begin{array}{l}\text { Simple therapy } \\
\text { Easy to use }\end{array}$ & Short therapeutic effects & Cutaneous atrophy \\
\hline $\begin{array}{l}\text { Mechlorethamine } \\
\text { (Nitrogen mustard) }\end{array}$ & $26 \%-76 \%$ & $\begin{array}{l}\text { Ointment causes } \\
\text { fewer reactions }\end{array}$ & $\begin{array}{l}\text { Important local reactions } \\
\text { Availability could be a problem }\end{array}$ & $\begin{array}{l}\text { Contact dermatitis } \\
\text { Secondary cutaneous } \\
\text { malignancy }\end{array}$ \\
\hline Carmustine & $86 \%$ & Rarely used & Important local reactions & $\begin{array}{l}\text { Medullary suppression } \\
\text { Telangiectasia }\end{array}$ \\
\hline Topical bexarotene & $21 \%$ & $\begin{array}{l}\text { Simple therapy } \\
\text { Easy to use }\end{array}$ & $\begin{array}{l}\text { Expensive } \\
\text { Availability could be a problem }\end{array}$ & $\begin{array}{l}\text { Irritant dermatitis, } \\
\text { pruritus, burning, skin } \\
\text { inflammation }\end{array}$ \\
\hline UVB & $75 \%-83 \%$ & $\begin{array}{l}\text { Good tolerability } \\
\text { Feasible }\end{array}$ & $\begin{array}{l}\text { Requires regular 2-3 times/week } \\
\text { treatment }\end{array}$ & Erythema, pruritus \\
\hline PUVA & $79 \%-88 \%$ & Very good response & $\begin{array}{l}\text { Requires regular 2-3 times/week } \\
\text { treatment }\end{array}$ & $\begin{array}{l}\text { Nausea, phototoxicity, } \\
\text { cutaneous malignancy }\end{array}$ \\
\hline $\begin{array}{l}\text { Radiotherapy } \\
\text { (electron beam) }\end{array}$ & $96 \%$ & Very good response & $\begin{array}{l}\text { Limited availability } \\
6-10 \text { weeks to complete } \\
\text { Permanent cutaneous side effects }\end{array}$ & $\begin{array}{l}\text { Pigmentation, pruritus, } \\
\text { alopecia, telangiectasia, } \\
\text { xerosis, anhidrosis, } \\
\text { cutaneous malignancy }\end{array}$ \\
\hline
\end{tabular}

Abbreviations: PUVA, psoralen plus ultraviolet A radiation; UVB, ultraviolet $B$.

The histological response to treatment has been evaluated in several published studies, although the results obtained have not been uniform. Ammann and Hunziker ${ }^{25}$ and Recio et a ${ }^{26}$ found complete histological cure of the plaques in full clinical remission and an absence of atypical lymphocyte infiltrates after treatment. Both described pigmentary changes with melanophages, fibrosis of the dermis, epidermal atrophy, and residual lymphocytes in the infiltrate. However, Edstrom et al found a residual infiltrate of atypical lymphocytes in some cases of lesions that were in full clinical remission. ${ }^{23}$ These findings may be explained by the limited penetration of light, which may not reach the deepest lymphocytes in MF plaques. In regard to these findings, Eich et al treated eight patients with MF tumors. ${ }^{27}$ The biopsy after treatment revealed remission of the infiltrate up to $1.5 \mathrm{~mm}$ in depth, but atypical lymphocytes persisted beyond $1.5 \mathrm{~mm}$. These histopathological findings make the follow-up of patients in complete remission necessary due to a possible relapse.

Table 5 Summary of the studies published of early-stage mycosis fungoides treated with photodynamic therapy

\begin{tabular}{|c|c|c|c|c|c|c|}
\hline & $\begin{array}{l}\text { Number of } \\
\text { lesions/patches }\end{array}$ & Light & Photosensitizer & $\begin{array}{l}\text { Type of } \\
\text { lesion }\end{array}$ & $\begin{array}{l}\text { Response/patches } \\
\text { treated }\end{array}$ & Relapse \\
\hline Svanberg et $\mathrm{al}^{20}$ & $4 / 2$ & Laser $630 \mathrm{~nm}$ & ALA & Patch & CR 2/4 & NS \\
\hline Wolf et $\mathrm{al}^{28}$ & $2 / 2$ & Visible light & ALA & Plaque & CR 2/2 & None in $3-6$ months \\
\hline Ammann and Hunziker ${ }^{25}$ & $1 / 1$ & Visible light & ALA & Plaque & CR I & NS \\
\hline Edstrom et $\mathrm{al}^{24}$ & $5 / 1$ & $630 \mathrm{~nm}$ & ALA & NS & CR 4/6 & NS \\
\hline Wang et $\mathrm{al}^{29}$ & $3 / 1$ & $635 \mathrm{~nm}$ & ALA & Periocular & CR & None in 33 months \\
\hline Orenstein et $\mathrm{al}^{30}$ & $6 / 2$ & $580-720 \mathrm{~nm}$ & ALA & $\begin{array}{l}\text { I patch } \\
2 \text { tumors }\end{array}$ & CR & None in 24 months \\
\hline Markham et $\mathrm{al}^{3 !}$ & $\mathrm{I} / \mathrm{I}$ & $580-740 \mathrm{~nm}$ & ALA & Tumors & CR & None in I year \\
\hline Edstrom et $\mathrm{al}^{23}$ & $12 / 10$ & $600-730 \mathrm{~nm}$ & ALA & $\begin{array}{l}10 \text { patches } \\
2 \text { tumors }\end{array}$ & $\begin{array}{l}\text { I/I0 plaques IR } \\
2 / 2 \text { tumors IR } \\
\text { Rest } P R \text { or } C R\end{array}$ & $\begin{array}{l}\text { In lesions with CR } \\
4-19 \text { months }\end{array}$ \\
\hline Leman et $\mathrm{al}^{32}$ & $2 / 1$ & $630 \mathrm{~nm}$ & ALA & Patch & $\mathrm{CR}$ & None in I year \\
\hline $\begin{array}{l}\text { Coors and Von den } \\
\text { Driesch }^{33}\end{array}$ & $7 / 5$ & $60-160 \mathrm{~nm}$ & ALA & $\begin{array}{l}5 \text { patches } \\
2 \text { tumors }\end{array}$ & CR & None in $12-18$ months \\
\hline Zane et $\mathrm{al}^{34}$ & $5 / 5$ & $635 \mathrm{~nm}$ & MAL & Patch & $\begin{array}{l}4 \mathrm{CR} \\
\mathrm{IPR}\end{array}$ & $\begin{array}{l}\text { No recurrence in lesions } \\
\text { with } C R \text { in } 12-34 \text { months }\end{array}$ \\
\hline Recio et $\mathrm{al}^{26}$ & $2 / 2$ & PDL 585 nm & ALA & Plaques & CR & None in 24 months \\
\hline Fernandez-Guarino et $\mathrm{al}^{35}$ & $24 / 12$ & 630 & MAL & Plaques & CR 6/12 & None in $6-36$ months \\
\hline
\end{tabular}

Abbreviations: ALA, aminolevulinic acid; CR, complete response; IR, incomplete response; MAL, methyl aminolevulinate; NS, not specified; PDL, pulsed dye laser; PR, partial response. 


\section{Published studies}

Since the first case of an MF plaque treated with PDT was published, ${ }^{20}$ a series of follow-up studies has been published (Table 5) that includes a total of 45 patients with $75 \mathrm{MF}$ lesions treated with PDT. ${ }^{23,24,28-35}$ The majority of researchers use delta-aminolevulinic acid and only two studies ${ }^{34,35}$ use its ester, methylaminolevulinate. Coherent or noncoherent red light is the light most commonly used due to its greater penetration of the skin. The overall response of all MF lesions treated in all these published small case series is $84 \%$. Despite the theory that the most infiltrated lesions have the worst response to this technique, all of the published tumor lesions were cured. This may be due to the tendency to publish treatment successes. If PDT is compared to other conventional treatment options for initial MF (Table 4), the response is similar or even superior with the advantage of having fewer side effects. The comparison with phototherapy is not entirely appropriate given that PDT is primarily applied in patients with few lesions (maximum of three to four) because of its local application.

Despite the simplicity of the technique, the optimal parameters have not been defined. Aminolevulinic acid and methylaminolevulinate have been shown to be effective and their occlusion time is variable according to different protocols. In general, the normal occlusion time is used (4-16 hours for aminolevulinic acid and 3 hours for methylaminolevulinate).$^{28-35}$ Light dosimetry and frequency of sessions varies significantly from one study to another. Nevertheless, the need for repeated sessions has been consistently reported since the first studies. ${ }^{25-35}$

\section{Adverse effects}

The primary advantage of PDT in the treatment of MF plaques is that it is an innocuous, noninvasive, comfortable, simple, relatively selective treatment with an excellent cosmetic result and no carcinogenic potential.

The treatment is generally well tolerated, although the majority of studies describe a mild burning sensation in patients. Short illumination times with high intensities were used in the first studies. However, subsequent studies began to use lower intensities and also had good results with less pain. ${ }^{23}$ Pain during illumination appears to be highly variable from one patient to another, ${ }^{34}$ and studies that used methylaminolevulinate as a photosensitizer instead of aminolevulinic acid showed excellent tolerance. ${ }^{34,35}$

Following illumination, the appearance of erythema and edema is common in the treated plaques. However, the formation of crusters and erosions is not common. When they do appear, they resolve within approximately 2-3 weeks. There may be mild pigment changes after full remission of the lesions, the most common being hyperpigmentation or hair loss. ${ }^{25,26,34}$

\section{Fluorescence diagnosis}

The fluorescence pattern of MF lesions was described by Orestein et al as mild and diffuse in patches and intense and well delineated in plaque or tumor lesions..$^{30}$ This work also indicated that fluorescence intensity decreases faster in patch lesions than in tumor lesions. Therefore, fluorescence diagnosis appears to be a useful tool in monitoring treatment. Posterior studies confirm these findings. ${ }^{26,35}$

\section{Summary of PDT}

PDT has been shown to be very useful in the treatment of a few plaques that do not respond to routine treatments or are in areas that are not easily accessible to phototherapy. It should not be considered in very large plaques or tumor lesions, as a poor response has been reported in these cases. ${ }^{23,24}$ Patient follow-up is necessary after treatment because delayed recurrences and an absence of histological cure has been reported in lesions that are in full clinical remission. ${ }^{24,27}$ PDT is a promising option that is under development, and further studies are needed in order to determine the proper procedure and its indications.

\section{Excimer laser and other light sources}

Phototherapy with $311 \mathrm{~nm}$ narrowband UVB has been used for treatment in the initial stages of MF with good results, ${ }^{36,37}$ and is one of the treatments mentioned in treatment guidelines. ${ }^{9}{ }^{910}$ With the same $308 \mathrm{~nm}$ wavelength, excimer $\operatorname{laser}^{38,43}$ and monochromatic excimer light ${ }^{44-46}$ have been studied in the treatment of MF, also with good results. There is also a published case of palmoplantar MF treated with a carbon dioxide laser with good results. Although this is the first case of this laser being used successfully in the treatment of MF, the carbon dioxide laser is not currently used. ${ }^{47}$

The excimer laser produces monochromatic coherent radiation in a short pulse through a hand piece with a circular spot. It has been widely used in psoriasis and vitiligo since the end of the 1990s and the first cases of its use in MF appeared in 2004. ${ }^{38}$ Table 6 summarizes the small case series that have been published on the treatment of earlystage MF with excimer laser. ${ }^{38-42}$ The primary advantage of this form of treatment is that it is phototherapy directed specifically at the lesion. This allows areas without lesions to 
Table 6 Summary of case series published on the treatment of initial mycosis fungoides with excimer laser

\begin{tabular}{|c|c|c|c|c|c|c|c|}
\hline Study & $\begin{array}{l}\text { Number } \\
\text { of patients }\end{array}$ & $\begin{array}{l}\text { Maximum peak } \\
\left(\mathrm{m} J / \mathrm{cm}^{2}\right)\end{array}$ & $\begin{array}{l}\text { Cumulative } \\
\text { dose }\left(\mathrm{J} / \mathrm{cm}^{2}\right)\end{array}$ & $\begin{array}{l}\text { Sessions/ } \\
\text { frequency }\end{array}$ & $\begin{array}{l}\text { Clinical } \\
\text { response }\end{array}$ & $\begin{array}{l}\text { Follow-up } \\
\text { period }\end{array}$ & Comments \\
\hline Passeron et $\mathrm{al}^{38}$ & 5 & NS & $2.4-16.1$ & $\begin{array}{l}|2-2| \text { sessions } \\
2 \text { sessions/week }\end{array}$ & $\begin{array}{l}\text { CR } 4 \\
\text { PR I }\end{array}$ & 3 months & $\begin{array}{l}\text { Complete histological } \\
\text { response in } 3 / 5 \text { patients }\end{array}$ \\
\hline Kontos et $\mathrm{al}^{39}$ & 2 & 450 & NS & $\begin{array}{l}14 \text { and } 22 \\
3 \text { sessions/week }\end{array}$ & $\begin{array}{l}\text { I CR } \\
\text { I IR }\end{array}$ & NS & $\begin{array}{l}\text { Clinical and histological } \\
\text { response coincide }\end{array}$ \\
\hline Upjohn et $\mathrm{al}^{40}$ & 8 & 600 & $6.56-8.35$ & $\begin{array}{l}20 \text { sessions } \\
2 \text { sessions/week }\end{array}$ & $\begin{array}{l}6 \mathrm{CR} \\
\text { I IR } \\
\text { I LF }\end{array}$ & 30 months & $\begin{array}{l}\text { Clinical and histological } \\
\text { response coincide } \\
3 / 6 \text { in CR recur at } 12 \text { months }\end{array}$ \\
\hline Passeron et $\mathrm{al}^{4 \mathrm{I}}$ & $\begin{array}{l}10 \\
29 \text { lesions }\end{array}$ & NS & $1.3-16 . \mid$ & $\begin{array}{l}6-46 \text { sessions } \\
2 \text { sessions/week }\end{array}$ & $\begin{array}{l}80 \% \mathrm{CR}^{*} \\
14 \% \mathrm{PR} \\
6 \% \text { IR }\end{array}$ & 8-26 months & $\begin{array}{l}\text { II\% recur at } 7 \text { months* } \\
\text { Clinical and histological } \\
\text { response coincide }\end{array}$ \\
\hline
\end{tabular}

Note: *Results analyzed by the number of lesions treated, not by the number of patients.

Abbreviations: CR, complete response; IR, incomplete response; LF, lost to follow-up; NS, not specified; PR, partial response.

avoid accumulating UV light, therefore having a lower risk of carcinogenesis. Another of its advantages is that it allows the application of higher fluencies in the affected skin as well as treatment of hidden areas such as folds or curves where conventional phototherapy does not reach.

The majority of these published studies apply two or three weekly sessions up to a total of twelve to 46 , with a cumulative dose of 2.4-16.1 J/cm² (Table 6). The rate of complete response is $50 \%-80 \%$ with response durations varying from 7 months to 30 months of follow-up. A posttreatment biopsy was performed in all of the studies, revealing histological cure in patients who were in full clinical remission. ${ }^{38-42}$ Application of this treatment has also been published successfully in a case of palmoplantar MF. ${ }^{43}$ The treatment is well tolerated, although it may cause hyperpigmentation of the lesions after treatment as well as erythema, edema, crusters, and blisters. ${ }^{38,39}$

The primary disadvantage of excimer laser therapy is that it is expensive and therefore inaccessible for use in daily clinical practice, and also requires training and management by a trained dermatologist. Nevertheless, the results of the small studies published show that this is a promising and good alternative treatment with few side effects and well tolerated for MF plaques that do not respond to regular treatments. However, more studies are needed with more patients in order to better evaluate the results and to optimize the usage parameters.

Monochromatic excimer light has been used in three studies, also with good results. ${ }^{44-46}$ The scarcity of published studies does not allow for conclusions to be made, but it may be a more advantageous treatment than the excimer laser. In these studies, only one weekly session is applied. There is a lower number of sessions (four to eleven) with a lower cumulative dose $\left(5-12 \mathrm{~J} / \mathrm{cm}^{2}\right)$. The complete response rates obtained were $100 \%$ of lesions with histological cure and remission periods from $12-28$ months. The authors did not report side effects other than transient hyperpigmentation. On the other hand, it is also a costly device - but less costly than the laser - and although its use also requires training, it is simpler.

\section{Topical treatments Topical imiquimod}

Topical imiquimod is an endogenous mediator inducer with antiviral and antitumor activity that increases the production of interferon- $\alpha$ and other cytokines on an intracellular level. ${ }^{48}$ Imiquimod acts on the activation of T-lymphocytes, increasing the activity of natural killer cells, tumor necrosis factor, and antigen-presenting cells in the skin. ${ }^{49}$ Systemic interferon is an effective treatment in MF and, given that imiquimod acts by increasing intracellular INF production, it has been explored as skin-directed treatment of MF plaques with good results.

The published cases of MF plaques treated with topical imiquimod are summarized in Table $7 .^{50-57}$ The majority are isolated cases or small case series. It is used at $5 \%$. The frequency of imiquimod application from the first studies has been reduced from daily application ${ }^{50,51}$ to three times or even once per week for months. ${ }^{56,57}$ This reduction increases treatment tolerance and decreases local irritation, although local irritation has been described as well tolerated since the first case $^{50,51}$ and there are cases of good results with application to the eyelid and penis. ${ }^{54,55}$ Two of the published cases combined treatment with topical imiquimod on the plaques together with systemic interferon with very good results, perhaps due to its potentiating effect by acting through the same mechanism. ${ }^{53}$ The histological response was examined in the majority of studies. In all cases except for one patient, the histological response coincided with the clinical response. However, none of these cases had a long follow-up period, making the long- 
Table 7 Published studies on mycosis fungoides treated with imiquimod

\begin{tabular}{|c|c|c|c|c|}
\hline Author & $\begin{array}{l}\text { Number } \\
\text { of patients }\end{array}$ & Mode of application & Clinical response & Comments \\
\hline Suchin et $\mathrm{al}^{50}$ & I & Once daily, 4 months & CR & Local irritation \\
\hline Dummer et $\mathrm{al}^{51}$ & I & Once daily, 8 weeks & CR & Histological response not evaluated \\
\hline Deeths et $\mathrm{al}^{52}$ & 6 & 3 times/week, 4 months & $2 \mathrm{CR}, 3 \mathrm{PR}, \mathrm{I}$ IR & Clinical and histological response coincide \\
\hline Onsun et $\mathrm{al}^{53}$ & I & 3 times/week, 6 months & $\mathrm{CR}$ & Complete histological response \\
\hline Soler-Machin et $\mathrm{al}^{54}$ & I & 3 times/week, 5 months & CR & Plaque on eyelid \\
\hline Ardigo et $\mathrm{al}^{7}$ & l & 5 times/week, 24 months & CR & Complete histological response \\
\hline Coors et $\mathrm{al}^{56}$ & 4 & 3-7 times/week, 8-16 weeks & $2 \mathrm{CR}, 2 \mathrm{IR}$ & Histological response not evaluated \\
\hline Chiam and Cham $^{55}$ & l & 3 times/week, 5 months & $\mathrm{CR}$ & Plaque on penis \\
\hline Martinez-Gonzalez et $\mathrm{al}^{57}$ & 4 & 3 times/week, 3 months & $4 \mathrm{CR}$ & Complete histological response in $3 / 4$ cases \\
\hline
\end{tabular}

Abbreviations: CR, complete response; IR, incomplete response; PR, partial response.

term efficacy of imiquimod still uncertain. In any case, patients should be periodically monitored as in all cases of early-stage MF being treated with skin-directed therapies.

Imiquimod is proposed as an alternative in the treatment of localized lesions that do not respond to regular treatments, although more studies with more patients are needed.

\section{Other topical treatments}

Topical methotrexate and tazarotene have also been used in the treatment of MF plaques in isolated studies. ${ }^{58,59}$ Recently, electrical stimulation has been used to deliver interferon- $\alpha$ into MF plaques. ${ }^{60}$

\section{Conclusion}

$\mathrm{MF}$ is the most common cutaneous lymphoma. Early-stage MF is the most common form of clinical presentation and skin-directed therapies are the habitual treatments. Skindirected therapies include topical corticosteroids, nitrogen mustard, carmustine, local or total body radiation therapy, topical bexarotene, and phototherapy. Other skin-directed therapeutic modalities have been developed in recent years with promising results. Topical imiquimod, excimer light sources, and PDT are alternatives for the treatment of plaques and patches that are refractory to habitual treatments. Their efficacy is comparable to conventional treatments, but large controlled studies are lacking. Their application is proposed as a promising alternative for nonresponsive lesions.

\section{Disclosure}

The author reports no conflicts of interest in this work.

\section{References}

1. Willemze R, Jaffe ES, Burg G, et al. WHO-EORTC classification for cutaneous lymphomas. Blood. 2005;105(10):3768-3785.

2. van Doorn R, van Haselen CW, van vorst Vader PC, et al. Mycosis fungoides: disease evolution and prognosis of 309 Dutch patients. Arch Dermatol. 2000;136(4):504-510.
3. Olsen E, Vonderheid E, Pimpinelli N, et al. Revisions to the staging and classification of mycosis fungoides and Sezary syndrome: a proposal of the International Society for Cutaneous Lymphomas (ISCL) and the cutaneous task force of the European Organization for Research and Treatment of Cancer (EORTC). Blood. 2007;110(6): 1713-1722.

4. Burg G, Dummer R, Haeffner A, Kempf W, Kadin M. From inflammation to neoplasia: mycosis fungoides evolved from reactive inflammatory conditions (lymphoid infiltrates) transforming into neoplastic plaques and tumours. Arch Dermatol. 2001;137(7):949-952.

5. Dummer R, Michie SA, Kell D, et al. Expression of bcl-2 protein and Ki-67 nuclear proliferation antigen in benign and malignant cutaneous T-cell infiltrates. J Cutan Pathol. 1995;22(1):11-17.

6. Olsen EA, Whittaker S, Kim YH, et al. Clinical end points and response criteria in mycosis fungoides and Sezary syndrome: a consensus statement of the International Society for Cutaneous Lymphomas, the United Stated Cutaneous Lymphoma Consortium, and the cutaneous lymphoma task force of the European Organisation for Research and Treatment of Cancer. J Clin Oncol. 2011;29(18):2598-2607.

7. Ardigò $\mathrm{M}$, Cota C, Berardesca E. Unilesional mycosis fungoides succesfully treated with topical imiquimod. Eur J Dermatol. 2006; 16(4):446.

8. Pimpinelli N, Olsen EA, Santucci M, et al. Defining early mycosis fungoides. J Am Acad Dermatol. 2005;53(6):1053-1063.

9. Hortwitz SM, Olsen EA, Duvic M, Porcu P, Kim YH. Review of the treatment of mycosis fungoides and Sezary syndrome: a stage-based approach. J Natl Compr Canc Netw. 2008;6(4):436-442.

10. Dummer R, Dreyling M. Primary cutaneous lymphoma: ESMO clinical recommendations for diagnosis, treatment and follow-up. Ann Oncol. 2008;19(Suppl 2):72-76.

11. Prince HM, Whittaker S, Hoppe RT. How I treat mycosis fungoides and Sezary syndrome. Blood. 2009;114(20):4337-4353.

12. Kaye FJ, Bunn PA Jr, Steinberg SM, et al. A randomized trial comparing combination of electron-beam radiation and chemotherapy with topical therapy in the initial treatment of mycosis fungoides. $N$ Engl J Med. 1989;321(26):1784-1790.

13. Zakheim HS, Kashani-Sabet M, Amin S. Topical corticosteroids for mycosis fungoides. Experience in 79 patients. Arch Dermatol. 1998;134(8):949-954.

14. Whittaker SJ, Foss FM. Efficacy and tolerability of currently avalaible therapies for the mycosis fungoides and Sezary syndrome variants of cutaneous T-cell lymphoma. Cancer Treat Rev. 2007;33(2): $146-160$.

15. Heald P, Melhmauer M, Martin AG, Crowley CA, Yocum RC, Reich SD. Topical bexarotene therapy for patients with refractory or persistent early-stage cutaneous T-cell lymphoma: results of the phase III clinical trial. J Am Acad Dermatol. 2003;49(5):801-815.

16. Herman JJ, Roenigk HH Jr, Hurria A, et al. Treatment of mycosis fungoides with photochemotherapy (PUVA): long-term follow-up. J Am Acad Dermatol. 1995;33(2 Pt 1):232-242. 
17. Hofer A, Cerroni L, Kerl H, Wolf P. Narrowband (311-nm) UVB therapy for small plaque parapsoriasis and early-stage mycosis fungoides. Arch Dermatol. 1999;135(1):1377-1380.

18. Lindelof B, Sigurgeirsson B, Tegner E, et al. PUVA and cancer risk: the Swedish follow-up study. Br J Dermatol. 1999;141(1):108-112.

19. Stern RS, Nichols KT, Vakeva LH. Malignant melanoma in patients treated for psoriasis with methoxsalen (psoralen) and ultraviolet A radiation (PUVA). The PUVA follow-up study. N Engl J Med. 1997; 336(15):1041-1045.

20. Svanberg K, Andersson T, Killander D, et al. Photodynamic therapy of non-melanoma malignant tumours of the skin using topical deltaamino levulinic acid sensitization and laser irradiation. Br J Dermatol. 1994;130(6):743-751.

21. Boehncke WH, Konig K, Ruck A, Kauffman R, Sterry W. In vitro and in vivo effects of photodynamic therapy in cutaneous T cell lymphoma. Acta Derm Venereol. 1994;74(3):201-205.

22. Rittenhouse-Diakun K, Van Leengoed H, Morgan J, et al. The role of transferrin receptor (CD71) in photodynamic therapy of activated and malignant lymphocytes using the heme precursor delta-amino-levulinic acid (ALA). Photochem Photobiol. 1995;61(5):523-528.

23. Edstrom DW, Portwit A, Ros AM. Photodynamic therapy with topical 5-aminolevulinic acid for mycosis fungoides: clinical and histological response. Acta Derm Venereol. 2001;81(3):184-188.

24. Edstrom DW, Ros AM, Parvit A. Topical 5-aminolevulinic acid-based photodynamic therapy for mycosis fungoides: a study of cell proliferation and apoptosis before and after therapy. J Invest Dermatol. 1998; 110(4):701.

25. Ammann R, Hunziker T. Photodynamic therapy for mycosis fungoides after topical photosensitization with 5-aminolevulinic acid [letter]. J Am Acad Dermatol. 1995;33(3):541.

26. Recio ED, Zambrano B, Alonso ML, et al. Topical 5-aminolevulinic acid photodynamic therapy for the treatment of unilesional mycosis fungoides: a report of two cases and review of the literature. Int $J$ Dermatol. 2008;47(4):410-413.

27. Eich D, Eich HT, Otte TH, Ghilescu HG, Stadler R. Photodynamic therapy of cutaneous $\mathrm{T}$ cell lymphoma in specific localizations. Hautarzt. 1999;50(2):109-114. German.

28. Wolf P, Fink-Puches R, Cerroni L, Kerl H. Photodynamic therapy for mycosis fungoides after photosensitization with 5-aminolevulinic acid. J Am Acad Dermatol. 1994;31(4):678-680.

29. Wang I, Bauer B, Anderson-Engels S, Svanberg S, Svanberg K. Photodynamic therapy utilizing delta aminolevulinic acid in nonmelanoma skins malignancies of the eyelid and periocular skin. Acta Ophthalmol Scand. 1999;77(2):182-188.

30. Orenstein A, Haik J, Tamir J, et al. Photodynamic therapy of cutaneous lymphoma using 5-aminolevulinic acid topical application. Dermatol Surg. 2000;26(8):765-769.

31. Markham T, Sheahan K, Collins P. Topical 5-aminolaevulinic acid photodynamic therapy for tumour-stage mycosis fungoides. $\mathrm{Br} \mathrm{J}$ Dermatol. 2001;144(6):1262-1263.

32. Leman JA, Dick DC, Morton CA. Topical 5-ALA therapy for the treatment of cutaneous T-cell lymphoma. Clin Exp Dermatol. 2002; 27(2):516-518.

33. Coors EA, von den Driesch P. Topical photodynamic therapy for patients with therapy-resistant lesions of cutaneous T-cell lymphoma. J Am Acad Dermatol. 2004;50(3):363-367.

34. Zane C, Venturini M, Sala R, Calzavara-Pinton P. Photodynamic therapy with mehtylaminolevulinate as a value treatment option for unilesional cutaneous T-cell lymphoma. Photodermatol Photoinmunol Photomed. 2006;22(5):254-258.

35. Fernandez-Guarino M, Harto A, Perez-Garcia B, Montull C, de las Heras E, Jaen P. Plaque-phase mycosis fungoides treated with photodynamic therapy: results in 12 patients. Actas Dermosifiliogr. 2010;101(9):785-791. Spanish.

36. Xiao T, Xia L, Yang ZH, He CD, Gao XH, Chen HD. Narrow-band ultraviolet B phototherapy for early stage mycosis fungoides. Eur $J$ Dermatol. 2008;18(6):660-662.
37. Clark C, Dawe RS, Evans AT, Lowe G, Ferguson J. Narrowband TL-01 phototherapy for patch-stage mycosis fungoides. Arch Dermatol. 2000;136(6):748-752.

38. Passeron T, Zakaria W, Ostovari N, et al. Efficacy of the 308-nm excimer laser in the treatment of mycosis fungoides. Arch Dermatol. 2004;140(10):1291-1293.

39. Kontos AP, Kerr HA, Malick F, Fivenson DP, Lim HW, Wong HK. 308-nm excimer laser for the treatment of lymphomatoid papulosis and stage IA mycosis fungoides. Photodermatol Photoinmmunol Photomed. 2006;22(3):168-171.

40. Upjohn E, Foley P, Lane P, et al. Long-term clearance of patch-stage mycosis fungoides with the 308-nm excimer laser. Clin Exp Dermatol. 2007;32(2):168-171.

41. Passeron T, Angeli K, Cardot-Leccia N, Perrin C, Lacour JP, Ortonne JP. Treatment of mycosis fungoides by $308-\mathrm{nm}$ excimer laser: a clinical and histological study in 10 patients. Ann Dermatol Venereol. 2007;134(3 Pt 1): 225-231. French.

42. Meisenheimer JL. Treatment of mycosis fungoides using a 308-nm excimer laser: two case studies [letter]. Dermatol Online J. 2006;12(7):11.

43. Jin SP, Jeon YK, Cho KH, Chung JH. Excimer laser therapy (308 nm) for mycosis fungoides palmaris et plantaris: a skin-directed and anatomically feasible treatment. Br J Dermatol. 2010;163(3):651-653.

44. Nistico S, Costanzo A, Saraceno R, Chimenti S. Efficacy of monochromatic excimer laser radiation $(308 \mathrm{~nm})$ in the treatment of early stage mycosis fungoides. Br J Dermatol. 2004;151(4):877-879.

45. Mori M, Campolmi P, Mavilia L, Rossi R, Cappugi P, Pimpinelli N. Monochromatic excimer light $(308 \mathrm{~nm})$ in patch-stage IA mycosis fungoides. J Am Acad Dermatol. 2004;50(6):943-945.

46. Nistico SP, Saraceno R, Schipani C, Costanzo A, Chimenti S. Different applications of monochromatic excimer light in skin diseases. Photomed Laser Surg. 2009;27(4):647-654.

47. Goldberg DJ, Stampien TM, Schwartz RA. Mycosis fungoides palmaris et plantaris: successful treatment with the carbon dioxide laser. $\mathrm{Br} J$ Dermatol. 1997;136(4):617-619.

48. Stanley MA. Imiquimod and the imidazoquinolones: mechanism of action and therapeutic potential. Clin Exp Dermatol. 2002;27(7):571-577.

49. Schon MP, Schon M. Imiquimod: mode of action. Br J Dermatol. 2007; 157(Suppl 2):8-13

50. Suchin KR, Junkins-Hopkins JM, Rook AH. Treatment of stage IA cutaneous T-cell lymphoma with topical application of the immune response modifier imiquimod. Arch Dermatol. 2002;138(9): 1137-1139.

51. Dummer R, Urosevic M, Kempf W, Kazakov D, Burg G. Imiquimod induces complete clearance of a PUVA-resistant plaque in mycosis fungoides. Dermatology. 2003;207(1):116-118.

52. Deeths MJ, Chapman JT, Dellavalle RP, Zeng C, Aeling JL. Treatment of patch and plaque stage mycosis fungoides with imiquimod $5 \%$ cream. J Am Acad Dermatol. 2005;52(2):275-280.

53. Onsun N, Ufacik H, Kural Y, Topcu E, Somay A. Efficacy of imiquimod in solitary plaques of mycosis fungoides. Int J Tissue React. 2005;27(4):167-172.

54. Soler-Machin J, Gilaberte-Calzada Y, Vera-Alvarez J, CoscojuelaSantaliestra C, Martinez-Morales J, Osan-Tello M. Imiquimod in treatment of palpebral micosis fungoides. Arch Soc Esp Oftalmol. 2006;81(4):221-223. Spanish.

55. Chiam LY, Cham YC. Solitary plaque mycosis fungoides of the penis responding to topical imiquimod therapy. Br J Dermatol. 2007;156(3): $560-562$.

56. Coors EA, Schuler G, von den Driesch P. Topical imiquimod as treatment for different kinds of cutaneous lymphoma. Eur J Dermatol. 2006; 16(4):391-393

57. Martinez-Gonzalez MC, Verea-Hernando M, Yebra-Pimentel MT, Del Pozo J, Mazaira M, Fonseca E. Imiquimod in micosis fungoides. Eur J Dermatol. 2008;18(2):148-152.

58. Demierre MF, Vachom L, Ho V, Sutton L, Cato A, Leyland-Jones B. Phase $1 / 2$ pilot study of methotrexate-laucopram topical gel for the treatment of patients with early-stage mycosis fungoides. Arch Dermatol. 2003;139(5):624-628. 
59. Apisarthanarax N, Talpur R, Ward S, Ni X, Kim HW, Duvic M. Tazarotene $0.1 \%$ gel for refractory mycosis fungoides lesions: an open-label pilot study. J Am Acad Dermatol. 2004;50(4):600-607.
60. Peycheva E, Daskalow I, Tsoneva I. Electrochemotherapy of mycosis fungoides by interferon- $\alpha$. Bioelectrochemistry. 2007;70(2): 283-286.

\section{Publish your work in this journal}

Clinical, Cosmetic and Investigational Dermatology is an international, peer-reviewed, open access, online journal that focuses on the latest clinical and experimental research in all aspects of skin disease and cosmetic interventions. All areas of dermatology will be covered; contributions will be welcomed from all clinicians and basic science researchers globally. This journal is indexed on CAS. The manuscript management system is completely online and includes a very quick and fair peer-review system, which is all easy to use. Visit http://www.dovepress.com/testimonials.php to read real quotes from published authors. 